\title{
A hybrid of Kano and QFD for ranking customers' preferences: A case study of bank Melli Iran
}

\author{
Mohammad Hassan Pourhasomi $^{\mathrm{a}}$, Alireza Arshadi Khamseh ${ }^{\mathrm{b}^{*}}$ and Yaser Ghorbanzad $^{\mathrm{c}}$
}

\begin{abstract}
${ }^{a}$ Master of Science, Department of Industrial Management, Science and Research Branch, Islamic Azad University, Tehran, Iran ${ }^{b}$ Assistant Professor Department of Industrial Engineering, Kharazmi University, Tehran, Iran

${ }^{c}$ Master of Industrial Management (OR), Department of Management and Economy, Science and Research Branch, Islamic Azad University, Tehran, Iran

\begin{tabular}{l}
\hline C H R O N I C L E \\
\hline Article history: \\
Received October 25, 2012 \\
Received in revised format \\
8 January 2013 \\
Accepted 20 January 2013 \\
Available online \\
February 12013 \\
\hline Keywords: \\
Bank Criteria \\
Customer Satisfaction \\
Quality Function Deployment \\
(QFD) \\
Kano Model \\
Analytical Hierarchy Process \\
(AHP)
\end{tabular}

A B S T R A C T

Nowadays, many service provider organizations compete to survive and surpass other competitors in the world. They apply new techniques and instruments to identify and to prioritize important criteria for their customers to gain customer satisfaction. Banks, as one of the service provider organizations, are no exception. Quality plays essential role in banking industry and customer' gratification is considered as one of the major and essential goals in this field. Recognition and awareness regarding the customers' needs and requirements would facilitate providing satisfactory services. It could be said that improved understanding, accurate identification and prioritization of bank customers' requirements are the keys to success for bank managers. The present study aims to integrate two approaches of Quality Function Deployment (QFD) and Kano's model through implementation of Analytical Hierarchy Process (AHP). This study proposes a novel approach to identify and to analyze the priorities of bank customers' requirements. The results indicate that the priorities of bank customers are different before and after integration of Kano's Model in the planning matrix of QFD.
\end{abstract}

\section{Introduction}

Banks are among the most influential economical firms in any country, privatization has tremendous effect on this industry, and it has changed into a competitive market in which they offer services considered valuable in customers' point of view (Yuksel et al., 2010). Today, banking industry necessitates applying new methods, effective customer-orientation, new technologies, providing services based on customers' requirements. Successful functions would also lead to making further profit, continual survival and progress, and higher efficiency for the banks (Zaribaf et al., 2011). The bank managers are well aware that customers' satisfaction with the quality of bank services is an important competitive advantage and source of making profit (Sureshchandar et al., 2009). Customers' satisfaction is the most important issue among bank managers and they need to know

Corresponding author.

E-mail: alireza.arshadikhamseh@gmail.com (A. Arshadi Khamseh)

(c) 2013 Growing Science Ltd. All rights reserved.

doi: 10.5267/j.msl.2013.02.001 
customer's requirements through different data collecting methods and information systems (Samadi \& Eskandari, 2011).

In order to attain the appropriate planning and marketing strategies for attracting new customers, all banks need to identify potential criteria, which influence customers' bank preferences (Almossawi, 2001). During the past few years, many service organizations have undergone basic changes. The primary objective of such organizations is to improve service quality and to match the service/product with customers' requirements and the banking sector and the financial institutes in Iran are no exception (pourhasomi et al., 2012). The banking services with high quality are the same as a product offered to the customers. Therefore, the bank managers should pay enough attention to the customers' requirements to prioritize the services based on the factors, which are valued by the customers. There are different techniques to identify the customers' requirements and to improve the quality of services in organizations.

Quality Function Deployment (QFD) and Kano's model are among the methods shown successful results in achieving the mentioned objectives. Therefore, the present study integrates these two techniques to optimally analyze, identify, classify, and prioritize the important criteria from the customers' point of view. The purpose of this study is to integrate the Kano's model in one of the phases of QFD to achieve an optimal identification, classification, and prioritization of customers' qualitative requirements. These data are implemented to provide a new customer-oriented prioritization so that the bank could achieve their goals and the customers could experience higher satisfaction. The primary objective of this study is to identify the necessary requirements of bank customers and how they are prioritized. The study also looks what the must-be, one-dimensional and attractive needs of customers. Finally, it includes how Kano's Model into QFD leading us to a new and different ranking of customers' needs. The results obtained by this study could be an effective step in guiding the bank managers to improve the quality of banking services that customers demand; hence, it could help banks improve their service qualities in national and international scope.

\section{Theoretical framework and literature review}

QFD is a service planning and development support method, which provides a structured way for service providers to assure quality and customer satisfaction while maintaining a sustainable competitive advantage (Akao, 1990). The objective of QFD is to enhance customer satisfaction, organizational integration of expressed customer needs and to improve profitability (Griffin, 1992). For new product development, quality function deployment (QFD) is a useful approach to maximize customer satisfaction. (Chen \& Ko, 2009). The process of QFD in the field of production includes the following phases: product planning (building the house of quality); product design (the necessities of design); process planning; and process control. The phases of QFD change to the following for services: planning the service; planning the features; and planning the operations (Chien \& Su, 2003).

Among the QFD phases, House of Quality (HOQ) is the most popular one, which involves documenting customers' requirements (Shen et al., 2000). The House of Quality, as the phase referred to frequently, is in fact a matrix-like table. This table matches the qualities and requirements demanded by the customers, called "WHATS", with the technical characteristics called "HOWS" (Hauser \& Clausing, 1988). The primary objective of HOQ is to detect customer requirements and weights for the product (WHATs) and to convert these needs into technical characteristics (HOWs). (Hsu et al., 2007). QFD starts with The House of Quality as the first phase. The House of Quality, unlike how it looks, includes important and beneficial contents, in case of precise development and design, which provide valuable data on service/product. Due to the extensiveness and variety of the concepts and data obtained by this phase, many organizations only get through this phase as the first and final phase of QFD (Rezaee et al., 2005). Fig. 1 represents a rather simplified example of The House of Quality. The House of Quality involves six subsidiary matrixes, which includes customer requirements matrix, planning matrix, correlation matrix, service/product features matrix, relationship matrix, technical matrix. 


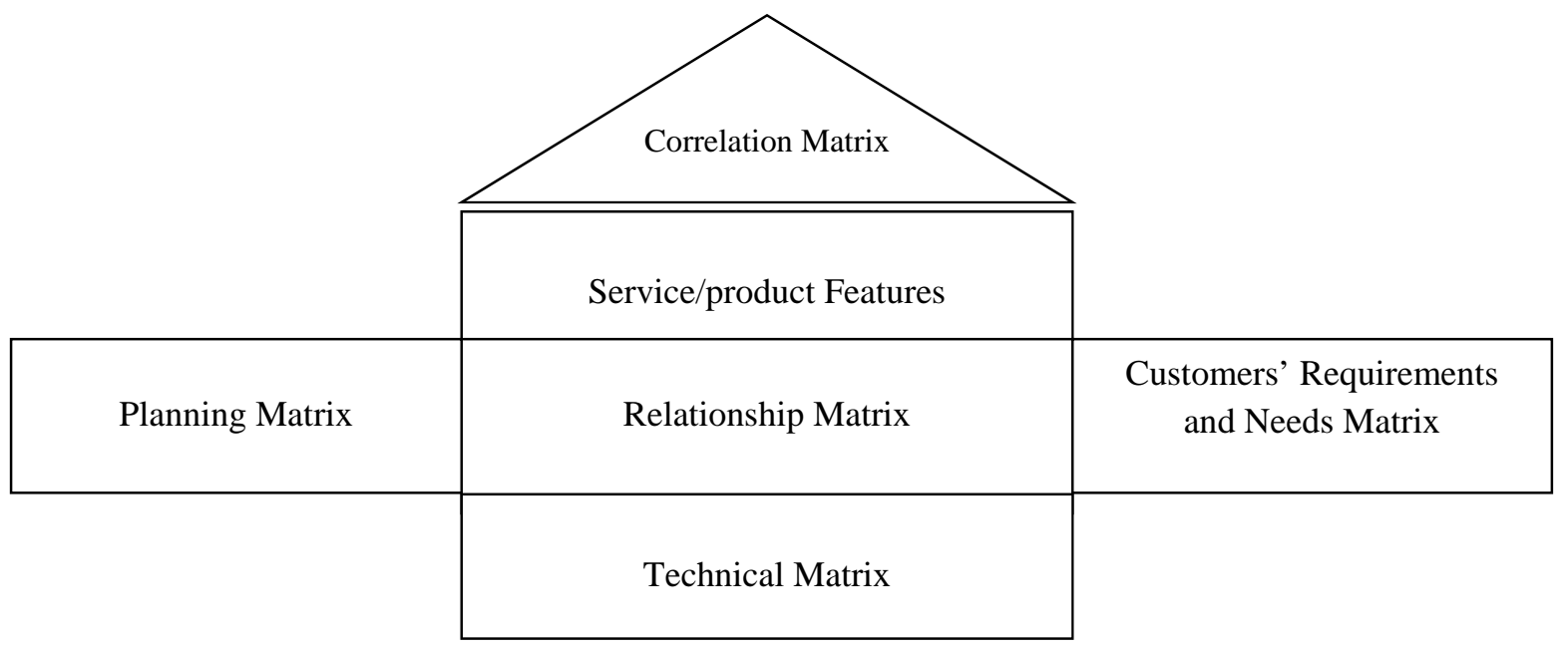

Fig. 1. The House of Quality

There are various studies conducted to identify the customers' needs and criteria for choosing the bank in different countries; some of them are presented here.

Kaufman (1967) investigated the customers and commercial firms in the USA to find the factors applied in bank selection decisions. According to the results of this study, the most significant factors reported by households were suitable location to home or place of business, length of bank-customers relationships and quality of services offered by the bank (Kaufman, 1967). In another study conducted by Mason and Mayer (1974), two groups of checking account customers in USA, high income and low income, were investigated for the factors used for selecting banks. Convenient location came was the first priority in the list. Other factors reported in the study include: friendly personnel; favorable loan experience; advice of friends; and influence of relatives.

Laroche et al. (1986) examined 140 households in Montreal, Canada and detected the factors used in selecting banks by the subjects. They reported that friendliness of staff plays the most important role in the bank selection process followed by hours of operations, size of waiting lines, convenience of location, and efficiency of personnel. Another study conducted by Erol et al. (1990) sought the bank selection criteria employed by customers of conventional and Islamic banks in Jordan. The results of this study revealed the ranking criteria as fast and efficient services, confidentiality of bank, bank's reputation and image, and friendliness of bank personnel.

Kaynak and Kucukemiroglu (1992) focused their study in Hong Kong on the significance of selection criteria used by consumers in choosing banks. The major factors were reported to be convenient location, financial counseling, available parking space nearby, vault location, and loans and mortgages. In another study in Malaysia Haron et al. (1994) investigated 301 Muslim and nonMuslim commercial bank customers to determine the selection criteria used in a dual banking environment. They reported that speed of transactions was the most important factor followed by fast and efficient services, friendliness of bank personnel, and confidentiality of bank (Haron et al, 1994).

Another study led by Boyd et al. (1994) used telephone survey to investigate the significance of 10 bank selection criteria in USA. In this study a selected list of ten criteria were presented to the subjects and they were asked to rank the most important factors. The factors that were ranked higher were: reputation, interest on savings accounts, interest charged on loans, quick service, location in city, hours of operation, availability of current accounts, friendliness of employees, modern facilities, drive-in service and other factors. Mylonakis et al. (1998) conducted an investigation on 811 bank customers in the in Greece looking for the important bank selection criteria. The results indicated that 
selection factors that were ranked as important factors by the customer were location convenience and quality of service (attention to customers, personalized service, no queues).

Almossawi studied bank selection criteria used by college students in Bahrain. This study focused on a sample of 1,000 students between the ages of 19-24 from the University of. Findings show that the important factors that affected college students' bank selection included: bank's reputation, friendliness of bank personnel, availability of parking space near the bank, and availability and location of automated teller machines (ATM) (Almossawi, 2001).

In another study, Bick and his colleagues examined the banking customers for their perception and expectations about value being delivered to them by retail banks in South Africa. The findings of this study indicated that customers did not show satisfaction with the service, products and level of customer intimacy offered by the banks. Thus, customers believed that they were not getting the value they expected (Bick et al., 2004). By conducting a study on households, Omar and Orakwue (2006) evaluated the relative importance of bank selection criteria taken into account by the bank customers in Nigeria. The results implied that safety of fund and efficient of service and speed of transaction were the most important factors applied by the customers in choosing their banks.

Blankson et al. (2007) investigated a number of cultural and country economic scenarios in order to find out the bank choice/selection criteria. Particularly, they tried to understand international consumers' selection criteria of banks employed by the customers in the USA, Taiwan, and Ghana. The obtained results showed that these countries did not show a significance difference. Mokhlis et al. (2008) studied undergraduate students of Universiti Malaysia Terengganu and found that secure feelings, ATM service and financial benefits were ranked as the most important criteria in selecting the bank.

Hinson et al. (2009), in an assignment, examined the importance of bank selection criteria. They collected the data from 2000 customers of 22 retail banks in Ghana. The results revealed that proximity was the most important factor from customers' viewpoint and recommendation by friends (word of mouth marketing) was least important factor. A study by Al-Ajmi et al. (2009) suggested that Islamic religious belief and social responsibility were the most important factors considered by the customers. In this study, 1000 questionnaires were distributed, with response rate of 65.5, among customers of conventional banks and Islamic banks in Bahrain. The findings of this study revealed that cost benefit was the third most important factor considered by Bahraini customers. Rashid and Kabir Hassan (2009) investigated selection criteria that affected Islamic banking in Bangladesh. The data for this study were collected from 371 customers of 5 banks in Dhaka City. According to the results, the most important factors were corporal efficiency, core-banking services and confidence. Rao and Sharma (2010) studied MBA students in India to find out about the bank selection criteria they employed. This study collected the data through questionnaire form 312 students who had a bank account. Findings showed that among the students under study, reliability was the most important factor in choosing a bank. Other significant factors included the responsiveness, value added services and convenience respectively.

According to the review of studies presented and the results obtained, it is obvious that the researchers have focused on different criteria in their studies, which is rooted in differences in cultural, geographical, political, and economic conditions. While some criteria are considered important by customers in a country, they might not show high significance in other countries. Therefore, there is a need for conducting a study according to the specific cultural, economic, political, and social conditions that affect the customers' choice of bank in Iran.

\section{The Planning Matrix of the House of Quality}

One of the subsidiary matrixes of The House of Quality is the planning matrix. This matrix is used as a convenient tool for the primary prioritization and re-prioritization of customers' requirements. This 
matrix includes the following steps: 1) customer requirements and quality demands: the matrix of The House of Quality starts with the customer and his qualitative requirements. To this aim, the customers' requirements are probed through methods such as market investigation, focus groups, observing the quality of product while using, the employees' ideas, the sales records of the products, reviewing the complaints, the mismatches, and data from offered service/product during the warranty period (Rezaee et al., 2005).

In this study, the interview and questionnaire are used as the tools to identify and determine the customers' requirements. 2) Customer importance rating: the Analytical Hierarchy Process (AHP) is recommended for rating the customers' requirements. This method is used for rating and deciding on alternatives when multiple criteria should be taken into account (ReVelle et al., 1998). In order to decide on the appropriate customers' rating, the researchers sought the ideas of customers and experienced staff in the organization. 3) Competition analysis: evaluating the service/product is a complex process due to the ambiguities (Baki et al., 2009).

The organizations that seek competition and effective presence in the market should ask the customer how the service/product rates in relation to the competition and qualitative features. The results of this step include a tremendous competitive advantage when the service/product offered by the competitor is not in a good position and there is the chance of success if the same service/product is offered considering the qualitative features (Rezaee, et al., 2005). Hence, in this step the customers evaluate the bank services in comparison to the major competitors in the same field. 4) Target value setting: many of the elements that are considered for QFD in industry, such as points of sale and improvement ratio, are not probed in service organizations and in some projects, it is difficult to determine the target values for customers' requirements and the qualitative features (Hwarng \& Teo, 2001).

During this step, the target values for each requirement by the customers are determined. The ideas of high-position managers in the banks are used to determine the target value for each requirement. 5) The improvement ratio of requirements: the improvement of each requirement in comparison to the present condition of the service/product is provided in this step. In this step, the degree of improvement of each requirement is determined through dividing the "bank plan" by "the present condition or bank evaluation”. 6) The final rating for requirements: this step involves deciding on the final weight of each requirement. To achieve this goal, for each requirement, the primary importance is multiplied by relevant improvement ratio and the result indicates the importance level and value of each qualitative feature.

\section{Kano’s model}

Kano's model, proposed by Kano et al. (1984) is a useful tool to understand customer needs and their impact on customer satisfaction. Kano categories different customers' needs based on how well they are able to achieve customer satisfaction. This model has been extensively applied as a useful tool for understanding the customers' needs and meeting their satisfaction (Wang \& Ji, 2010). This model is widely known as an effective method for rating the customers' needs and understanding their nature (Garibay et al., 2010). A questionnaire is used as the tool for categories of customers' requirements in this model. Kano questionnaire classifies the requirements under the categories of must-be, onedimensional, and attractive attributes as well as those that the customers do not take into account. In this questionnaire, there are a couple of questions for each requirements type and the customer provides the answer by choosing one of the alternative items. The first question evaluates customers' reaction to adding a feature to a service/product (the functional dimension) and the second one evaluates customers' reaction to eliminating the same feature (the non-functional dimension). The features for service/product could be classified according to the answers to these questions. Table 1 
represents the evaluation and categories of customers' requirements by this questionnaire (Berger et al., 1993).

Table 1

The Kano evaluation and rating table

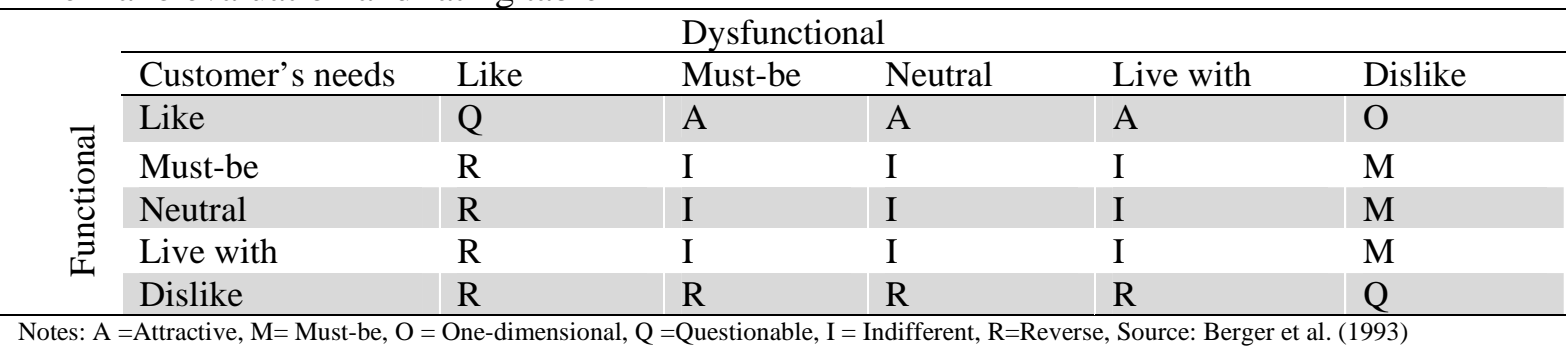

As it is shown in Table 1, the answer to each question is presented in the first line and column of this matrix. The intersections between these questions are used to decide on the categories for requirements.

\section{Analytical Hierarchy Process (AHP)}

Thomas L. Saaty first proposed the Analytical Hierarchy Process (AHP) in 1979. The first professional work in this regard was conducted by him published in his book Analytical Hierarchy Process in 1980. AHP is specifically suitable for decision makings that involve multi-criteria (Fong \& Choi, 2000). AHP is a flexible and reliable decision making process that guides the decision makers in determining the priorities and choosing the best options. It is also applicable in the cases where a simultaneous consideration of qualitative and quantitative dimensions is needed. AHP technique reduces the complexities of decisions through pairwise comparisons and in this way it helps the decision makers to come to the best choice and it also offers a logical and clear reasons for that best choice (Rao \& Davim, 2008).

The operational application of AHP includes four major steps: a) modeling a hierarchical representation of the issue that includes goal, criteria for evaluation, and alternatives (Ghodsipour, 2008); b) the first step to establish the priorities is led through judgments or pairwise comparisons of elements in decision situation; c) the judgments should be synthesize to achieve the priorities and in this step the weight for each matrix is obtained (Saaty, 1994); d) Inconsistency Ratio: in this step the group decision making matrix is used for checking the inconsistencies of judgments. In other words it could be said that the reliability of the method is evaluated through the inconsistencies rate.

\section{The Conceptual Model}

The combination of QFD and Kano' Model could be considered as a practical tool for a better understanding of the customers' requirements. The key factor in this method is how the requirements in QFD are associated with Kano's Model (Garibay et al., 2010). QFD is applicable as a significant tool in understanding and hearing the voice of customers. The major organizations should identify the criterion or feature that is of high importance to the customers. Kano's Model categorizes the mustbe, one-dimensional, and attractive attributes and verifies the features that would drive customers' satisfaction and it could be integrated into the QFD matrix. As a result, the Kano's Model could be implemented as a complementary tool in QFD for analyzing and classifying the customers' requirements. The integration of these two models could facilitate the offering of products/services according to customers' needs and requirements. The conceptual model of this study is achieved through the integration of Kano Model into the planning matrix of The House of Quality that is represented in Fig. 2. As it could be seen in Fig. 2, three major steps are taken into account in designing this model. These major steps are introduced in details. 


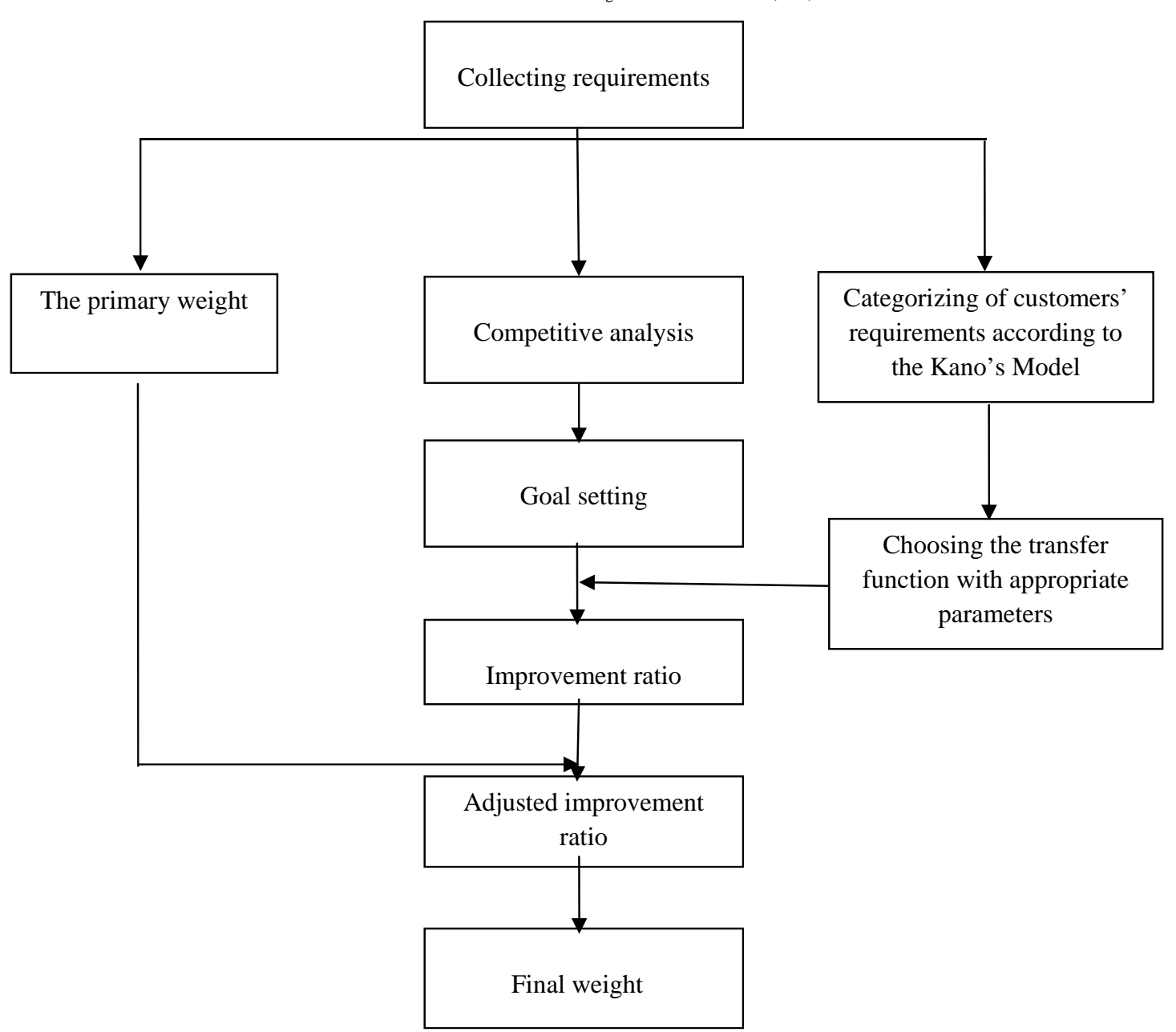

Fig. 2. The process model of the adjustment of improvement ration and Final weight the requirements according to the Kano's Model

The first step - understanding and receiving the voice of the customer: this step was conducted in two phases. In the first phase, the customers were identified and categorized. In this study, after discussing with the experts (bank managers) those customers who referred to the five branches under study during the time scope for study were selected as the major customers. These customers were selected since they were the main and direct customers for bank services and had the highest interaction with the bank. In the next phase, the customers' needs and requirements were obtained through interviews and questionnaires.

The second step - designing the matrix of The House of Quality: in this step, after determining the requirements and qualitative necessities, the matrix of The House of Quality that is obtained through AHP. Then the competitive analysis, bank programs, the improvement ratio, and the marginal significance of customers' requirements are obtained. The process is explained in the previous section.

The third step - Integrating the Kano's Model in the matrix of The House of Quality: in this step, the Kano's Model is integrated in the matrix of The House of Quality in two phases. First, the customers' requirements are classified into must-be, one-dimensional, and attractive attributes through the Kano's questionnaire. Then the improvement ratio for each single requirement is obtained though the transfer function. The only selection factor used is adjustment parameter (K), which is selected according to the requirement categories based on Kano's Model. Selecting the appropriate comparative parameter for transfer function, the improvement ratio for each requirement is moderated. 


\section{Adjusted Improvement Ratio (IR adj $)$}

Adjusted Improvement Ratio is obtained though:

$\mathrm{IR}_{\mathrm{adj}}=\left(\mathrm{IR}_{\mathrm{o}}\right)^{1 / \mathrm{K}}$

where

$\mathrm{IR}_{\mathrm{adj}}$ : adjusted improvement ratio

$\mathrm{IR}_{0}$ : original improvement ratio

K: comparative parameters of Kano’s Model for each category of customers’ requirements.

The (K) parameters for the must-be, one-dimensional, and attractive attributes are .5, 1 and 2 respectively.

In this way, applying the comparative parameter of transfer function, the improvement ratio in The House of Quality matrix is moderated in each category of requirements and the effects of this moderation is directly represented in the marginal significance. In this study, establishing the priorities of requirements was conducted through the AHP technique and a set of determining factors including the bank policies and customers' viewpoints and the improvement ratio was the result of dividing the programs by the existing condition of bank regarding each requirement. Also the improvement ratio was moderated though the application of improvement transfer function and the effects of hierarchy parameters in Kano's Model. Therefore, it could be said that the adjusted marginal significance, obtained through multiplying the primary significance and the adjusted improvement ratio, includes a set of factors affecting the priority of the requirements as well as their hierarchy. The marginal significance of requirements could be used as a criterion for bank improvement and development programs.

\section{Methodology}

In line with the research goal, the present study is of applied nature and considering the method it is descriptive that is categorized under the main heading of field research. The statistical population of this study included all of the customers that refer to the bank for receiving services. In order to determine the size of sample, first the "Identifying customers' requirements" questionnaire was distributed among 50 individuals as the pilot and the standard deviation of .262 was calculated for this sample. Then, the sample size for the study was calculated by the following formula at the significant level of .05 and the resulting number was 105. Taking into account the possible lack of cooperation by the samples, 250 individuals were selected through random sampling as the sample. From this sample size 190 questionnaires were retuned.

$$
n=\frac{N \times z_{\alpha / 2}^{2} \times p \times q}{\varepsilon^{2} \times(N-1)+z_{\alpha / 2}^{2} \times p \times q},
$$

where $N$ is the population size, $p=1-q$ represents the yes/no categories, $z_{\alpha / 2}$ is CDF of normal distribution and finally $\varepsilon$ is the error term. Since we have $p=0.5, z_{\alpha / 2}=1.96$ and $N=15000$, the number of sample size is calculated as $n=105$

Also the size of sample was calculated in Kano's questionnaire with the following formula and the sample size of 136 was obtained. The same as the previously mentioned stage, 250 individuals were selected through random sampling to compensate for possible lack of cooperation. In general, after omitting the incomplete questionnaires, 185 questionnaires were returned. In addition, according to the mentioned formula, the sample size for the questionnaire of "bank evaluation regarding the fulfillment of customers' requirements in comparison to the competitors" was calculated as 110 
individuals and for the questionnaire of "prioritizing and rating the banks programs" was calculated as 90 individuals. And the calculated Cronbach's alpha was .830 for the questionnaire of "identifying the customers' requirements”, .810 for the Kano's questionnaire, .835 for the questionnaire of "evaluating competitors" and .890 for the questionnaire of "priorities of bank programs". The mentioned calculated numbers for Cronbach’s alpha show high reliability for the questionnaires.

In order to identify the customers' requirements first the experienced individuals (the bank managers) are interviewed in person. Then, according to the international studies conducted in this field and the results of interviews twenty qualitative requirements and wants by customers are gathered. These requirements are presented in Table 2.

\section{Table 2}

The requirements and qualitative necessities for customers

\begin{tabular}{ll}
\hline Item number & Customers' requirements \\
\hline 1 & Flexibility in collecting the delayed loans \\
2 & Neat and polished look for the staff \\
3 & Applying the banking technologies such as phone banking service, ATMs, and online \\
& banking services \\
4 & Accountability and responsibility of the staff \\
5 & Interest rates for bank loans \\
6 & Interest rates for deposits \\
7 & Lower rates of banking service charges \\
8 & Showing concern and attention while helping the customers \\
9 & Convenient location of the bank for ease of access and parking space \\
10 & Understanding the specific needs of customers by the bank \\
11 & Adjusting working hours of different parts of bank to the customers' needs \\
12 & Showing enough consideration to the customers and lowering the waiting time for receiving \\
& the services \\
13 & Facilities including money counter machines, ventilation systems, and comfortable chairs \\
14 & Following the rules and regulations by the bank managers and staff \\
16 & Staff's willingness to help the customers \\
17 & A clean and comfortable environment \\
18 & Flexibility in accepting the bails for loans and mortgages \\
19 & Balancing the time needed for receiving and refunding the banking facilities \\
20 & Friendly and polite behaviors of staff \\
\hline
\end{tabular}

After this step, the questionnaire of “identifying the customers' requirements" was distributed among the customers. This questionnaire addressed two main issues: first, evaluating the identified abovementioned requirements by the customers; second, rating the priority levels of requirements on a Likert scale including 1-5 levels (where 1 showed the lowest level and 5 showed the highest level of priority). After completing this questionnaire, 10 requirements that showed the highest degree of importance from the customers' point of views are rated as follows:

1. Adjusting working hours of different parts of bank to the customers’ needs,

2. Accountability and responsibility of the staff,

3. Applying the banking technologies such as phone banking service, ATMs, and online banking services,

4. Showing enough consideration to the customers and lowering the waiting time for receiving the services, 
5. Interest rates for deposits,

6. Following the rules and regulations by the bank managers and staff,

7. Convenient location of the bank for ease of access and parking space,

8. Balancing the time needed for receiving and refunding the banking facilities,

9. Friendly and polite behaviors of staff,

10. Awareness and expertise of bank staff and manager in responding to the customers' needs.

After this stage, the customers' needs were primarily prioritized. To this aim, a group was selected for surveying and deciding on the primary priorities. The members of this group included the three bank managers as experts and three bank customers. The questionnaire of "Rating the customers' requirements according to customers and bank's views" was distributed among this group and after that the validity of the questionnaire was evaluated according to the inconsistency ratio. Since some of the questionnaires did not show acceptable validity, this step was repeated and the questionnaires were distributed among the experts and customers again to achieve a higher validity. The validity that was calculated for the second time according to the revised questionnaires showed acceptable validity. Next, the questionnaire of 'bank evaluation regarding the fulfillment of customers' requirements in comparison to the competitors" was distributed to compare the given bank and a major competitor regarding the customers' requirements identified and the customers rated the requirements on a Likert scale from 1-7 (where 1 showed the lowest and 7 showed the highest degree of importance). In the next step, the questionnaire of "prioritizing and rating the banks programs" was distributed among the experts (bank managers) and they rate the requirements on a 1-7 liker scale (where 1 showed the lowest and 7 showed the highest degree of importance) in terms of some factors including the limitations and opportunities. Finally, 250 Kano's questionnaires were distributed among the customers with the aim of investigating the must-be, one-dimensional and attractive needs. After excluding the incomplete cases 185 complete questionnaires were used in data analysis.

\section{Findings}

In this section, the theoretical concepts were combined with the authentic data and the final analysis is done. As the first step, the planning matrix of The House of Quality was drawn according to the research conceptual model. Ten requirements of the customers, which were collected through interview and questionnaire and showed higher frequencies, were used for drawing the matrix. The technique of AHP was applied to obtain the primary significance level. The hierarchy of decision making process was developed after discussing with the experts. The customers' requirements were considered as the goal and the bank and customers' viewpoints were taken as the criteria for deciding on the options. Ten requirements of customers were taken as the options for pairwise comparisons. Table 3 summarizes the results for decision making and rating according to the mentioned decisionmaking criteria.

\section{Table 3}

The normalized matrix and significant levels of the decision making criteria

\begin{tabular}{lccc}
\hline Criteria & Customers' viewpoint & Bank’s viewpoint & Priority (weight) \\
\hline Customers' viewpoint & .746 & .398 & .57 \\
Bank’s viewpoint & .254 & .602 & .43 \\
\hline
\end{tabular}

The geometric means for the pairwise comparisons were calculated for each criterion. In the next step, the priorities of options are drawn according to each criterion. Accordingly, the matrix of geometric means, as the criterion for decision making was normalized. The Weigh (priority) for each criterion was specified through calculating mean for each line of criteria in the matrix. The results of final rating and prioritization through AHP are represented in Table 4. 
Table 4

The prioritization of requirements in Analytical Hierarchy Process (AHP)

\begin{tabular}{|c|c|c|c|c|}
\hline \multirow[t]{2}{*}{ Item } & \multirow[t]{2}{*}{ Customers' requirements } & \multirow{2}{*}{$\begin{array}{c}\text { Customers } \\
.57 \\
\end{array}$} & \multirow{2}{*}{$\begin{array}{r}\text { Bank } \\
.43\end{array}$} & \multirow[t]{2}{*}{$\begin{array}{l}\text { Weigh (final } \\
\text { prioritization) }\end{array}$} \\
\hline & & & & \\
\hline 1 & Adjusting working hours of different parts of bank to the customers' needs & .0485 & .1650 & .0985 \\
\hline 2 & Accountability and responsibility of the staff & .1377 & .1440 & .1403 \\
\hline 3 & $\begin{array}{l}\text { Applying the banking technologies such as phone banking service, ATMs, and } \\
\text { online banking services }\end{array}$ & .1440 & .2137 & .1738 \\
\hline 4 & $\begin{array}{l}\text { Showing enough consideration to the customers and lowering the waiting time for } \\
\text { receiving the services }\end{array}$ & .2510 & .1264 & .1973 \\
\hline 5 & Interest rates for deposits & .0920 & .0723 & .0834 \\
\hline 6 & Following the rules and regulations by the bank managers and staff & .0563 & .0529 & .0547 \\
\hline 7 & Convenient location of the bank for ease of access and parking space & .0501 & .0864 & .0656 \\
\hline 8 & Balancing the time needed for receiving and refunding the banking facilities & .0920 & .0705 & .0827 \\
\hline 9 & Friendly and polite behaviors of staff & .0760 & .0428 & .0617 \\
\hline 10 & $\begin{array}{l}\text { Awareness and expertise of bank staff and manager in responding to the customers' } \\
\text { needs }\end{array}$ & .0524 & .0260 & .0409 \\
\hline
\end{tabular}

In this step, the prioritizing of the requirements was done according to some effective factors such as bank policies and the customers' views. As Table 4 shows, the highest priority pertains to "Showing enough consideration to the customers and lowering the waiting time for receiving the services" and the lowest priority is related to "Awareness and expertise of bank staff and manager in responding to the customers' needs”. In the third phase of planning matrix of House of Quality concerns evaluating competition. In this phase, the customers based on mentioned priorities compare the bank with one major competitor (Mellat bank). As represented in Table 5, the bank under study showed higher and better performance on some of the priorities and lower performance compared with others. In some of the cases, the two banks showed the same level of performance. The results of this step are used in deciding on and setting the goals and plans for the bank. The next step includes determining the goal for each of the mentioned priorities (customers' requirements). For this step, the questionnaire of "prioritizing and rating the banks programs" was distributed among the managers and they rated the requirements on a Likert scale of 1-7 levels according to a set of factors including limitations and opportunities. As the next step, the improvement ratio was calculated for each requirement. The improvement ratio was calculated through dividing the bank's plans by the present condition (bank evaluation) regarding each requirement. Finally, the ranking of the requirements were determined based on the improvement factor as well as the primary significance. The ranking of requirements results from multiplying the primary significance by the improvement factor shown in Table 5.

Table 5

The matrix of The House of Quality and calculation of final significance before the integration

\begin{tabular}{|c|c|c|c|c|c|c|c|c|}
\hline \multirow[t]{2}{*}{ Item } & \multirow[t]{2}{*}{ Customers' requirements } & \multirow[t]{2}{*}{$\begin{array}{l}\text { Primary } \\
\text { weight }\end{array}$} & \multicolumn{2}{|c|}{$\begin{array}{c}\text { Competition } \\
\text { analysis }\end{array}$} & \multirow[t]{2}{*}{$\begin{array}{c}\text { Goal/ } \\
\text { program }\end{array}$} & \multirow[t]{2}{*}{$\begin{array}{l}\text { Improveme } \\
\text { nt factor }\end{array}$} & \multirow[t]{2}{*}{$\begin{array}{c}\text { Final } \\
\text { Weight }\end{array}$} & \multirow[t]{2}{*}{$\begin{array}{l}\text { bank } \\
\text { ranking }\end{array}$} \\
\hline & & & Melli & Mellat & & & & \\
\hline 1 & $\begin{array}{l}\text { Adjusting working hours of different parts of bank to } \\
\text { the customers' needs }\end{array}$ & .0985 & 5 & 5 & 6 & 1.2 & .118 & 5 \\
\hline 2 & Accountability and responsibility of the staff & .1403 & 4 & 5 & 6 & 1.5 & .210 & 3 \\
\hline 3 & $\begin{array}{l}\text { Applying the banking technologies such as phone } \\
\text { banking service, ATMs, and online banking services }\end{array}$ & .1738 & 5 & 4 & 7 & 1.4 & 243 & 2 \\
\hline 4 & $\begin{array}{l}\text { Showing enough consideration to the customers and } \\
\text { lowering the waiting time for receiving the services }\end{array}$ & 1973 & 4 & 5 & 6 & 1.5 & .296 & 1 \\
\hline 5 & Interest rates for deposits & .0834 & 6 & 5 & 7 & 1.17 & .097 & 6 \\
\hline 6 & $\begin{array}{l}\text { Following the rules and regulations by the bank } \\
\text { managers and staff }\end{array}$ & .0547 & 5 & 4 & 6 & 1.2 & .066 & 10 \\
\hline 7 & $\begin{array}{l}\text { Convenient location of the bank for ease of access } \\
\text { and parking space }\end{array}$ & .0656 & 3 & 4 & 4 & 1.34 & .088 & 7 \\
\hline 8 & $\begin{array}{l}\text { Balancing the time needed for receiving and } \\
\text { refunding the banking facilities }\end{array}$ & .0827 & 4 & 3 & 6 & 1.5 & .124 & 4 \\
\hline 9 & Friendly and polite behaviors of staff & 0617 & 4 & 5 & 5 & 1.25 & .077 & 8 \\
\hline 10 & $\begin{array}{l}\text { Awareness and expertise of bank staff and manager in } \\
\text { responding to the customers' needs }\end{array}$ & .0409 & 3 & 4 & 5 & 1.67 & .068 & 9 \\
\hline
\end{tabular}


Next, Kano questionnaire was distributed among the customers in order to identify the must-be, onedimensional, and attractive attributes. Table 6 represents the customers' requirements ranked based on the frequencies.

Table 6

Results of the Kano questionnaire

\begin{tabular}{|c|c|c|c|c|c|c|c|c|}
\hline Item number & A & $\mathbf{M}$ & $\mathbf{O}$ & $\mathbf{Q}$ & $\mathbf{I}$ & $\mathbf{R}$ & Total & Kano category \\
\hline 1 & 14 & 45 & 121 & 1 & 1 & 3 & 185 & One-dimensional \\
\hline 2 & 9 & 137 & 34 & - & 3 & 2 & 185 & Must-be \\
\hline 3 & 33 & 10 & 139 & 3 & - & - & 185 & One-dimensional \\
\hline 4 & 11 & 148 & 20 & 1 & - & 5 & 185 & Must-be \\
\hline 5 & 43 & 121 & 15 & 2 & 2 & 2 & 185 & Must-be \\
\hline 6 & 126 & 34 & 21 & 1 & - & 3 & 185 & Attractive \\
\hline 7 & 143 & 18 & 16 & 1 & 6 & 1 & 185 & Attractive \\
\hline 8 & 48 & 13 & 123 & 1 & - & - & 185 & One-dimensional \\
\hline 9 & 145 & 7 & 26 & - & 2 & 5 & 185 & Attractive \\
\hline 10 & 12 & 140 & 27 & 2 & 4 & - & 185 & Must-be \\
\hline Total & 3 & 4 & 3 & & & & & \\
\hline
\end{tabular}

As Table 6 shows, 4 attributes are ranked as the Must-be needs. These cases include: 1 . Accountability and responsibility of the staff, 2. Showing enough consideration to the customers and lowering the waiting time for receiving the services, 3. Interest rates for deposits and, 4 . Awareness and expertise of bank staff and manager in responding to the customers' needs. The Must-be needs should necessarily be provided in the service/product, and their absence in the service/product would lead to customers' dissatisfaction.

This category helps preventing the customers' dissatisfaction and is considered as the introductory step to come on the market; in fact, it is effective in overcoming the competitors. three attributes are ranked as the One-dimensional needs: 1 . Adjusting working hours of different parts of bank to the customers' needs, 2. Applying the banking technologies such as phone banking service, ATMs, and online banking services, 3. Balancing the time needed for receiving and refunding the banking facilities. The One-dimensional needs are demanded explicitly by the customers and attending to this category would lead to more satisfaction on the side of customers and survival of the company in the market.

Finally, the attractive attributes include three options: 1 . Following the rules and regulations by the bank managers and staff, 2. Convenient location of the bank for ease of access and parking space and, 3. Friendly and polite behaviors of staff. Although meeting the needs in this category would drive customers' further satisfaction, their absence would not result in dissatisfaction since the customers do not expect and mention them explicitly. Addressing the needs in this category helps the company to take the position of a leader in the market. Finally, the adjusted improvement ratio and adjusted marginal significance are analyzed through the Kano categories and adjustment parameter (K). Table 7 summarizes the results of the combination of Kano's Model in the matrix of The House of Quality.

As Table 5 Table and 7 reveal, the bank priorities indicate differences before and after the integration of Kano's Model in The House of Quality matrix. As Table 7 suggests, the improvement ratio of the Must-be attributes increases, that was due to the reverse effect of adjustment parameter of the basic requirements that doubled the improvement ratio. The improvement ratio of the One-dimensional attributes was not changed that is caused by the reverse effect of adjustment parameters of the onedimensional attributes that kept the improvement ratio constant. The improvement ratio of the attractive attributes showed a decrease, which was a result of the reverse effect of adjustment parameter that increased improvement ratio to 1.2. 
Table 7

The matrix of The House of Quality and calculation of final significance after combination

\begin{tabular}{|c|c|c|c|c|c|c|c|c|c|c|c|}
\hline \multirow[t]{2}{*}{ Item } & \multirow[t]{2}{*}{ Customers' requirements } & \multirow[t]{2}{*}{$\begin{array}{l}\text { Primary } \\
\text { weight }\end{array}$} & \multicolumn{2}{|c|}{$\begin{array}{l}\text { Competition } \\
\text { Analysis }\end{array}$} & \multirow[t]{2}{*}{$\begin{array}{l}\text { Goal/ } \\
\text { program }\end{array}$} & \multirow[t]{2}{*}{$\begin{array}{l}\text { Improvement } \\
\text { ratio }\end{array}$} & \multirow[t]{2}{*}{$\begin{array}{l}\text { Final } \\
\text { weight }\end{array}$} & \multirow[t]{2}{*}{$\begin{array}{l}\text { Kano’s } \\
\text { Category }\end{array}$} & \multirow{2}{*}{$\begin{array}{l}\text { Adjusted } \\
\text { improvement } \\
\text { ratio }\end{array}$} & \multirow{2}{*}{$\begin{array}{l}\text { Final } \\
\text { Adjusted } \\
\text { Weight }\end{array}$} & \multirow[t]{2}{*}{$\begin{array}{l}\text { bank } \\
\text { ranking }\end{array}$} \\
\hline & & & Melli & Mellat & & & & & & & \\
\hline 1 & $\begin{array}{l}\text { Adjusting working hours of } \\
\text { different parts of bank to the } \\
\text { customers' needs }\end{array}$ & .0985 & 5 & 5 & 6 & 1.2 & .118 & $\begin{array}{l}\text { One- } \\
\text { dimensional }\end{array}$ & 1.2 & .118 & 5 \\
\hline 2 & $\begin{array}{l}\text { Accountability and responsibility } \\
\text { of the staff }\end{array}$ & .1403 & 4 & 5 & 6 & 1.5 & .210 & Must-be & 2.25 & .316 & 2 \\
\hline 3 & $\begin{array}{l}\text { Applying the banking technologies } \\
\text { such as phone banking service, } \\
\text { ATMs, and online banking services }\end{array}$ & .1738 & 5 & 4 & 7 & 1.4 & .243 & $\begin{array}{l}\text { One- } \\
\text { dimensional }\end{array}$ & 1.4 & .243 & 3 \\
\hline 4 & $\begin{array}{l}\text { Showing enough consideration to } \\
\text { the customers and lowering the } \\
\text { waiting time for receiving the } \\
\text { services }\end{array}$ & .1973 & 4 & 5 & 6 & 1.5 & .296 & Must-be & 2.25 & .443 & 1 \\
\hline 5 & Interest rates for deposits & .0834 & 6 & 5 & 7 & 1.17 & .097 & Must-be & 1.37 & .114 & 6 \\
\hline 6 & $\begin{array}{l}\text { Following the rules and regulations } \\
\text { by the bank managers and staff }\end{array}$ & .0547 & 5 & 4 & 6 & 1.2 & .066 & Attractive & 1. 1 & .060 & 10 \\
\hline 7 & $\begin{array}{l}\text { Convenient location of the bank for } \\
\text { ease of access and parking space }\end{array}$ & .0656 & 3 & 4 & 4 & 1.34 & .088 & Attractive & 1.16 & .076 & 8 \\
\hline 8 & $\begin{array}{l}\text { Balancing the time needed for } \\
\text { receiving and refunding the } \\
\text { banking facilities }\end{array}$ & .0827 & 4 & 3 & 6 & 1.5 & .124 & $\begin{array}{l}\text { One- } \\
\text { dimensional }\end{array}$ & 1.5 & .124 & 4 \\
\hline 9 & $\begin{array}{l}\text { Friendly and polite behaviors of } \\
\text { staff }\end{array}$ & .0617 & 4 & 5 & 5 & 1.25 & .077 & Attractive & 1.12 & .069 & 9 \\
\hline 10 & $\begin{array}{l}\text { Awareness and expertise of bank } \\
\text { staff and manager in responding to } \\
\text { the customers' needs }\end{array}$ & .0409 & 3 & 4 & 5 & 1.67 & .068 & Must-be & 2.78 & .113 & 7 \\
\hline
\end{tabular}

In addition, the final weight of the must-be attributes also revealed an increase, which was resulted from the modified improvement ratio and the effects it exerted on the primary weight. For example, the final weight for "Accountability and responsibility of the staff" increased from .210 to .316, which was followed from an increase of improvement ratio from 1.5 to 2.25 . While the final weights show a decrease for attractive attributes, the final weights for one-dimensional attributes remain constant.

\section{Conclusion}

Although QFD has been successfully applied in many service sections, there are few studies that integrate Kano's Model and QFD in a single study in the field of banking and credit institutions. In recent years, due to the introduction of private section banks to the Iran's economy, the role of this institution has increased. Therefore, there is a need for improving, developing and increasing the quality of services provided to the customers. Undoubtedly, those banks, which offer services with superior quality and quantity, are able to attract more applicants. This study was an attempt to propose a new approach through integrating the Kano's Model and QFD in order to identify and rate the customers' requirements.

To this aim, first the most significant requirements of customers were identified. Then the final rating of the identified requirements was determined through the matrix of The House of Quality. These final requirements were categorized according to the hierarchy of Kano's Model, which classifies the requirements into the three categories of must-be, one-dimensional, and attractive attributes. These requirements were then modified through transfer function of improvement ratio and finally a new rating resulted. As the findings indicate, the first customers' requirement, which ranked higher was "Showing enough consideration to the customers and lowering the waiting time for receiving the services”. Consequently, it is recommended to the bank managers to arrange for training courses for the staff. The training courses should aim to increase the staff' banking knowledge in different areas, including the customer-orientation principles. These training courses should not be limited to the novice employees, rather they should include the other employees as well in order to upgrade their banking knowledge. 
The second requirement that ranked higher was "accountability and responsibility of the staff”. Accordingly, bank managers are suggested to employ qualifies employees who are well-aware of their responsibility and accountability toward the customers. The third priority was related to "Applying the banking technologies such as phone banking service, ATMs, and online banking services". It is suggested to the banks to develop their services through expanding the electronic banking services including services offered through phone and SMS, improving the ATM systems, the online services, and the bandwidth. As the results of this study indicated, the fourth priority was "Balancing the time needed for receiving and refunding the banking facilities". Hence, the banks should create an information system in order to offer information about the conditions for receiving the banking facilities, the amount of banking facilities that could be offered, the documents required for receiving loans and other facilities. In general, according to the results obtained by the present study and due to the necessity for attending to the customers' needs and requirements and tanking a customer-oriented approach to banking, the following recommendations are presented:

1. Due to the significance of meeting the must-be and One-dimensional attributes, the banks could set up programs that target these attributes; since lack of response to these requirements provokes dissatisfaction in customers.

2. Since the customers' interests and expectations are subject to change through the time, the process of identifying the customers' needs should be reestablished periodically.

3. This study applied AHP technique to the rating of requirements. Future studies could utilize other optimizing methods including goal programming, fuzzy logic, and etc.

\section{Acknowledgement}

The authors would like to express deep gratitude to editors of Management Science Letters for their good comments and the managers of Melli bank and the bank customers for their kind cooperation through the course of this study.

\section{References}

Akao, Y. (2004). Quality function deployment: integrating customer requirements into product design. Productivity Press.

Almossawi, M. (2001). Bank selection criteria employed by college students in Bahrain: an empirical analysis. International Journal of Bank Marketing, 19(3), 115-125.

Al-Ajmi, J., Abo Hussain, H., \& Al-Saleh, N. (2009). Clients of conventional and Islamic banks in Bahrain: How they choose which bank to patronize. International Journal of social Economics, 36(11), 1086-1112.

Baki, B., Basfirinci, C. S., Ilker Murat, A. R., \& Cilingir, Z. (2009). An application of integrating SERVQUAL and Kano's model into QFD for logistics services: a case study from Turkey. Asia Pacific Journal of Marketing and Logistics, 21(1), 106-126.

Blankson, C., Cheng, J. M. S., \& Spears, N. (2007). Determinants of banks selection in USA, Taiwan and Ghana. International Journal of Bank Marketing, 25(7), 469-489.

Berger, C., Blauth, R., Boger, D., Bolster, C., Burchill, G., DuMouchel, W., \& Walden, D. (1993). Kano's methods for understanding customer-defined quality. Center for Quality Management Journal, 2(4), 3-36.

Boyd, W.L., Leonard, M., \& White, C. (1994). Customer preferences for financial services: an analysis. International Journal of Bank Marketing, 12(1), 9-15.

Bick, G., Brown, A. B., \& Abratt, R. (2004). Customer perceptions of the value delivered by retail banks in South Africa. International Journal of Bank Marketing, 22(5), 300-318.

Chen, L.H., \& Ko, W.C. (2009). Fuzzy approaches to quality function deployment for new product design. Fuzzy Sets and Systems, 160, 2620-2639. 
Chien, T. \& Su, C. (2003). Using the QFD concept to resolve customer satisfaction strategy decisions. International Journal of Quality and Reliability Management, 20(3), 345-359.

Erol, C., Kaynak, E., \& Radi, E. B. (1990). Conventional and Islamic banks: patronage behaviour of Jordanian customers. International Journal of Bank Marketing, 8(4), 25-35.

Fong, P.S W., \& Choi, S. K. Y. (2000). Final contractor selection using the analytical hierarchy process. Construction Management and Economics, 18, 547-557.

Garibay, C., Gutierrez, H., \& Figueroa, A. (2010). Evaluation of a digital library by means of quality function deployment (QFD) and the Kano's model. The Journal of Academic Librarianship, 36(2), 125-132.

Griffin, A. (1992). Evaluating QFD's use in US firms as a process for developing products. Journal of Product Innovation Management, 9(2), 171-187.

Ghodsipour , H. (2008). Analytical Hierarchy Process (AHP). $3^{\text {rd }}$ ed., Tehran: Amir Kabir University Publications, (In Persian).

Haron, S., Ahmad, N., \& Planisek, S.L. (1994). Bank patronage factors of Muslim and non-Muslim customers. International Journal of Bank Marketing, 12(1), 32-40.

Hinson, R., Owusu-Frimpong, N., \& Dasah, J. (2009). Key motivations for bank patronage in Ghana. International Journal of Bank Marketing, 27(5), 381-399.

Hauser, J.R., \& Clausing, D. (1988). The house of quality. Harward Business Review, 66(3), 63-73.

Hsu, C. H., Chang, T.M., Wang, S.Y, \& Lin, P.Y. (2007). Integrating Kano's model into qualityfunction deployment to facilitate decision analysis for service quality. Proceedings of the 8th WSEAS Int. Conference on Mathematics and Computers in Business and Economics, Vancouver, Canada, June 19-21.

Hwarng, H.B., \& Teo, C. (2001). Translating customers' voices into operations requirements: a QFD application in higher education. International Journal of Quality \&Reliability Management, 18(2), 195-226.

Kano, N., Seraku, N., Takahashi, F., \& Tsuji, S. (1984). Attractive quality and must-be quality. Hinshitsu: The Journal of the Japanese Society For Quality Control, April, 39-48.

Kaufman, G.G. (1967). A survey of business firms and households view of a commercial bank. Report to the Federal Reserve Bank of Chicago, Appleton, University of Wisconsin, Madison, WI.

Kaynak, E., \& Kucukemiroglu, O. (1992). Bank and product selection: Hong Kong. International Journal of Bank Marketing, 10(1), 3-16.

Laroche, M., Rosenblatt, J.A., \& Manning, T. (1986). Services used and factors considered important in selecting a bank: an investigation across diverse demographic segments. International Journal of Bank Marketing, 4(1), 35-55.

Mason, J.B., \& Mayer, M.L. (1974). Differences between high-and-low-income savings and checking account customers. The Magazine of Bank Administration, 65, 48-52.

Mylonakis, J., Malliaris, P.G., \& Siomkos, G.J. (1998). Marketing-driven factors influencing savers in the hellenic bank market. Journal of Applied Business Research, 14(2), 109-116.

Mokhlis, S., Mat, N.H.N., \& Salleh, H.S. (2008). Commercial bank selection: The case of undergraduate students in Malaysia. International Review of Business Research Papers, 14(5), 258-270.

Omar, O., \& Orakwue, E. (2006). Gender-based choice of retail banking in Nigeria. Journal of Business \& Retail Management Research (JBRMR), May 2006.

Pourhasomi, M. H., Arshadi Khamseh, A., \& Seyed Hosseini, S.M. (2012). Integrating Kano's model into quality function deployment (QFD) to optimally identify and prioritize the needs of higher education (case study: Engineering Faculty of Tarbiat Moallem University). Interdisciplinary Journal of Contemporary Research in Business, 4(4), 233-246.

ReVelle, J.B. Moran, J.W., \& Cox, C.A. (1998). The QFD Handbook. John Wiley \& Sons, New York, NY. 
Rao, R.V., \& Davim J. P. (2008). A decision-making framework model for material selection using a combined multiple attribute decision-making method. International Journal of Advanced Manufacturing Technology, 35, 751- 760.

Rashid, M., \& Kabir Hassan, M., (2009). Customer demographics affecting bank selection criteria, Preference, and market segmentation: Study on domestic Islamic banks in Bangladesh. International journal of Business and Management, 4(6), 131-146.

Rao, S., \& Sharma R. K. (2010). Bank selection criteria employed by MBA students in Delhi: An empirical analysis. Journal of business studies Quarterly, 1(2), 56-69.

Rezaee, K., Hosseini Ashtiani, H., Houshyar, M., \& Vaziri, F. (2005). QFD: a customer oriented approach to planning and improving the product. Tehran: RWTUU and Atena Publications.

SureshChandar, G. S., Rajendran, C., \& Anantharaman, R. N. (2009). The relationship between service quality and customer satisfaction: a factor specific approach. Journal of services marketing, 16(4), 363-379.

Shen, X. X., Tan, K. C., \& Xie, M. (2000). Benchmarking in QFD for quality improvement. International Benchmarking Journal, 7(4), 282-291.

Saaty, T.L. (1994). Fundamentals of decision making and priority theory with the analytical hierarchy process. RWS Publications, Pittsburgh, PA.

Samadi, A., \& Eskandari, S. (2011). The effects of service quality on customer satisfaction on Melli bank in Toyserkan, Hamedan, Iran (based on the Servqual Model). Management Quarterly, 8(20), 21-30.

Yuksel, A . Yuksel , F., \& Bilim, Y. (2010). Destination attachment: Effects on customer satisfaction and cognitive affective and cognitive loyalty. Journal of Tourism management, 31(2), 274-284.

Wang, T., \& Ji, P. (2010). Understanding customer needs through quantitative analysis of Kano's model. International Journal of Quality \& Reliability Management, 27(2), 173-184.

Zaribaf, M., Hosseini, S. M., \& Bozorgmehr, B. (2011). A contrastive study of behevioural preferences of electronic banking and the traditional banking users (case study: the willingness of Mellat Bank customers in Semnan to use the electronic banking services). Management Quarterly, 8(21), 55-66. 